\title{
A New Dicyemid from Octopus hubbsorum (Mollusca: Cephalopoda: Octopoda)
}

\author{
Author(s) :Sheila Castellanos-Martinez, M. Carmen Góómez, F. G. Hochberg, Camino Gestal, and
} Hidetaka Furuya

Source: The Journal of Parasitology, 97(2):265-269. 2011.

Published By: American Society of Parasitologists

DOI: $10.1645 / \mathrm{GE}-2577.1$

URL: http://www.bioone.org/doi/full/10.1645/GE-2577.1

BioOne (www.bioone.org) is a a nonprofit, online aggregation of core research in the biological, ecological, and environmental sciences. BioOne provides a sustainable online platform for over 170 journals and books published by nonprofit societies, associations, museums, institutions, and presses.

Your use of this PDF, the BioOne Web site, and all posted and associated content indicates your acceptance of BioOne's Terms of Use, available at www.bioone.org/page/terms of use.

Usage of BioOne content is strictly limited to personal, educational, and non-commercial use. Commercial inquiries or rights and permissions requests should be directed to the individual publisher as copyright holder. 


\title{
A NEW DICYEMID FROM OCTOPUS HUBBSORUM (MOLLUSCA: CEPHALOPODA: OCTOPODA)
}

\author{
Sheila Castellanos-Martinez, M. Carmen Gómez*, F. G. Hochberg†, Camino Gestal, and Hidetaka Furuyał \\ Instituto de Investigaciones Marinas (CSIC), Eduardo Cabello 6, 36208 Vigo, Spain. e-mail: hfuruya@bio.sci.osaka-u.ac.jp
}

\begin{abstract}
A new species of dicyemid mesozoan is described from Octopus hubbsorum Berry, 1953, collected in the south of Bahia de La Paz, Baja California Sur, México. Dicyema guaycurense n. sp. is a medium-size species that reaches about 1,600 $\mu \mathrm{m}$ in length. It occurs in folds of the renal appendages. The vermiform stages are characterized as having 22 peripheral cells, a conical calotte, and an axial cell that extends to the base of the propolar cells. Infusoriform embryos consist of 39 cells; 1 nucleus is present in each urn cell and the refringent bodies are solid. This is the first of a dicyemid species from a host collected in the Gulf of California.
\end{abstract}

Dicyemid mesozoans (Phylum Dicyemida) are the most common endosymbionts typically found in the renal sac of benthic cephalopod molluscs. In total, 114 species of dicyemids have so far been reported in at least 43 species of benthic cephalopods. Most of them were found to be host specific (Furuya, 1999). Dicyemids are distributed in a variety of geographical localities, i.e., Okhotsk Sea, Japan Sea, western and northeastern Pacific Ocean, New Zealand, northern Indian Ocean, Mediterranean, northwestern and eastern Atlantic Ocean, and Antarctic Ocean. In Mexico, the dicyemid mesozoan fauna has received little attention. Dicyemids belonging to Dicyema and Dicyemennea have been described off the Pacific coast of Baja California, Mexico (McConnaughey, 1941, 1949a, 1949b). More recently, Dicyema shorti was described from the Gulf of Mexico (Furuya et al., 2002).

In the present article, we describe a new species from Octopus hubbsorum Berry, 1953, collected off Bahia de La Paz, Baja California Sur, México. This is the first dicyemid described from the Gulf of California.

\section{MATERIALS AND METHODS}

In this study, 53 individuals of $O$. hubbsorum were examined for dicyemids from 2003 to 2004. Host specimens were obtained from fishermen, who collected them in the south of Bahia de La Paz, Gulf of California, Mexico. Small pieces of the renal organ with attached dicyemids were removed and smeared on glass microscope slides. The smears were fixed immediately in Bouin's fluid and then stored. They were stained in Ehrlich's hematoxylin or ferric hematoxylin and counterstained in eosin. Stained smears were mounted with low-viscosity synthetic resin (Citoseal, Kalamazoo, Michigan). Dicyemids were observed with Zeiss and Olympus light microscopes at magnifications up to $\times 2,000$. Measurements and drawings were made with the aid of an ocular micrometer and a drawing tube, respectively.

The terminology for cell names used in the description of infusoriform larvae is based on Nouvel (1948), Short and Damian (1966), Furuya et al. (1992a, 1997), and Furuya (1999).

Specimens of the dicyemids are deposited in the Coleccion Helmintologica del Museo de Historia Natural of the Universidad Autonoma de Baja California Sur (CPMHN-UABCS 250, CPMHN-UABCS 251, CPMHN-UABCS 252), México. The syntypes and host specimen

Received 25 June 2010; revised 11 October 2010; accepted 14 October 2010.

* Departamento de Biología Marina, Universidad Autónoma de Baja California Sur, Apartado Postal 19 B, 23080 La Paz, Baja California Sur, México.

$\dagger$ Department of Invertebrate Zoology, Santa Barbara Museum of Natural History, 2559 Puesta del Sol, Santa Barbara, California 93105.

\$To whom correspondence should be addressed: Department of Biology, Graduate School of Science, Osaka University, 1-1 Machikaneyama, Toyonaka, Osaka 560-0043, Japan.

DOI: 10.1645/GE-2577.1 (symbiotype) are deposited in the collection of the Department of Invertebrate Zoology, Santa Barbara Museum of Natural History, Santa Barbara, California (SBMNH 357585, SBMNH 357586).

\section{DESCRIPTION}

\section{Dicyema guaycurense $\mathrm{n}$. sp.}

(Figs. 1, 2; Table I)

Diagnosis: Large dicyemid; body lengths to $1,600 \mu \mathrm{m}$. Calotte shape conical. Vermiform stages with 22 peripheral cells: 4 propolar cells +4 metapolar cells +2 parapolar cells +12 trunk cells. Infusoriform embryos with 39 cells; refringent bodies solid; and 1 nucleus present in each urn cell.

Nematogens (Figs. 1a, 2a, d): Body lengths 380-1,109 $\mu \mathrm{m}$, widths $23-$ $70 \mu \mathrm{m}$; widest in region of diapolars; trunk width mostly uniform. Peripheral cell number 22 (Table I): 4 propolar cells +4 metapolar cells +2 parapolar cells +10 diapolar cells +2 uropolar cells. Calotte conical in shape, rounded anteriorly; cilia on calotte about $6 \mu \mathrm{m}$ long, oriented anteriorly. Propolar cells and their nuclei smaller than metapolar cells and their nuclei, respectively. Propolar cells occupy anterior 35-50\% of calotte length when viewed laterally (Figs. 1a, b, 2d, e). Axial cell cylindrical, rounded anteriorly; cell extends forward to middle of metapolar cells. About 20 vermiform embryos present in axial cells of large individuals.

Vermiform embryos (Figs. 1c, 2f, $g$ ): Full-grown vermiform embryos range from 56 to $69 \mu \mathrm{m}$ in length, from 11 to $16 \mu \mathrm{m}$ in width. Peripheral cell number 22 (Table I); trunk cells arranged in opposed pairs. Anterior end of calotte rounded. Axial cell rounded anteriorly; extends to base of propolar cells; nucleus usually located in center of axial cell. Axial cell of full-grown embryos often with as many as 4 agametes; 2 in each side of axial cell nucleus (Figs. 1c, 2g).

Rhombogens (Figs. 1b, 2b, c, e): Body longer than nematogens, lengths $545-1,600 \mu \mathrm{m}$, widths $27-71 \mu \mathrm{m}$. Peripheral cell number typically 22 (Table I). Calotte conical, rounded anteriorly. Axial cell shape and anterior extent similar to nematogens. From 1 to 4 infusorigens present in axial cell of each parent individual. About 20 infusoriform embryos present in axial cells of large individuals. Accessory nuclei usually present in trunk cells.

Infusorigens (Fig. 1d; $n=20$ ): Mature infusorigens small sized; composed of 4-15 (mode 9) external cells (oogonia and primary oocytes) $+2-5$ (mode 4 ) internal cells (spermatogonia, primary spermatocytes, and secondary spermatocytes) $+4-13$ (mode 7) spermatozoa. Mean diameter of fertilized eggs, $12.6 \mu \mathrm{m}$; of spermatozoa, $1.8 \mu \mathrm{m}$. Axial cell round or ovoid, diameters $9-25 \mu \mathrm{m}$.

Infusoriform embryos (Figs. 1e, $f, 2 h-j ; n=20$ ): Full-grown embryos large, lengths average $29.6 \pm 2.4 \mu \mathrm{m}$ (excluding cilia; mean $\pm \mathrm{SD}$ ); length:width:height ratio 1.0:0.84:0.80; shape ovoid, bluntly rounded posteriorly; cilia at posterior end $7 \mu \mathrm{m}$ long. Refringent bodies present, solid; occupy anterior $40 \%$ of embryo length when viewed laterally (Fig. 1e). Cilia project from ventral internal cells into urn cavity (Fig. 2j). Capsule cells contain large granules. Mature embryos with 39 cells: 35 somatic +4 germinal cells. Somatic cells of several types present: external cells cover large part of anterior and lateral surfaces of embryo (2 enveloping cells); external cells with cilia on external surfaces (2 paired dorsal cells +1 median dorsal cell +2 dorsal caudal cells +2 lateral caudal cells +1 ventral caudal cell +2 lateral cells +2 posteroventral lateral cells), external cells with refringent bodies ( 2 apical cells); external cells without cilia ( 1 couvercle cell +2 anterior lateral cells +2 first ventral cells + 2 second ventral cells +2 third ventral cells); internal cells with cilia (2 

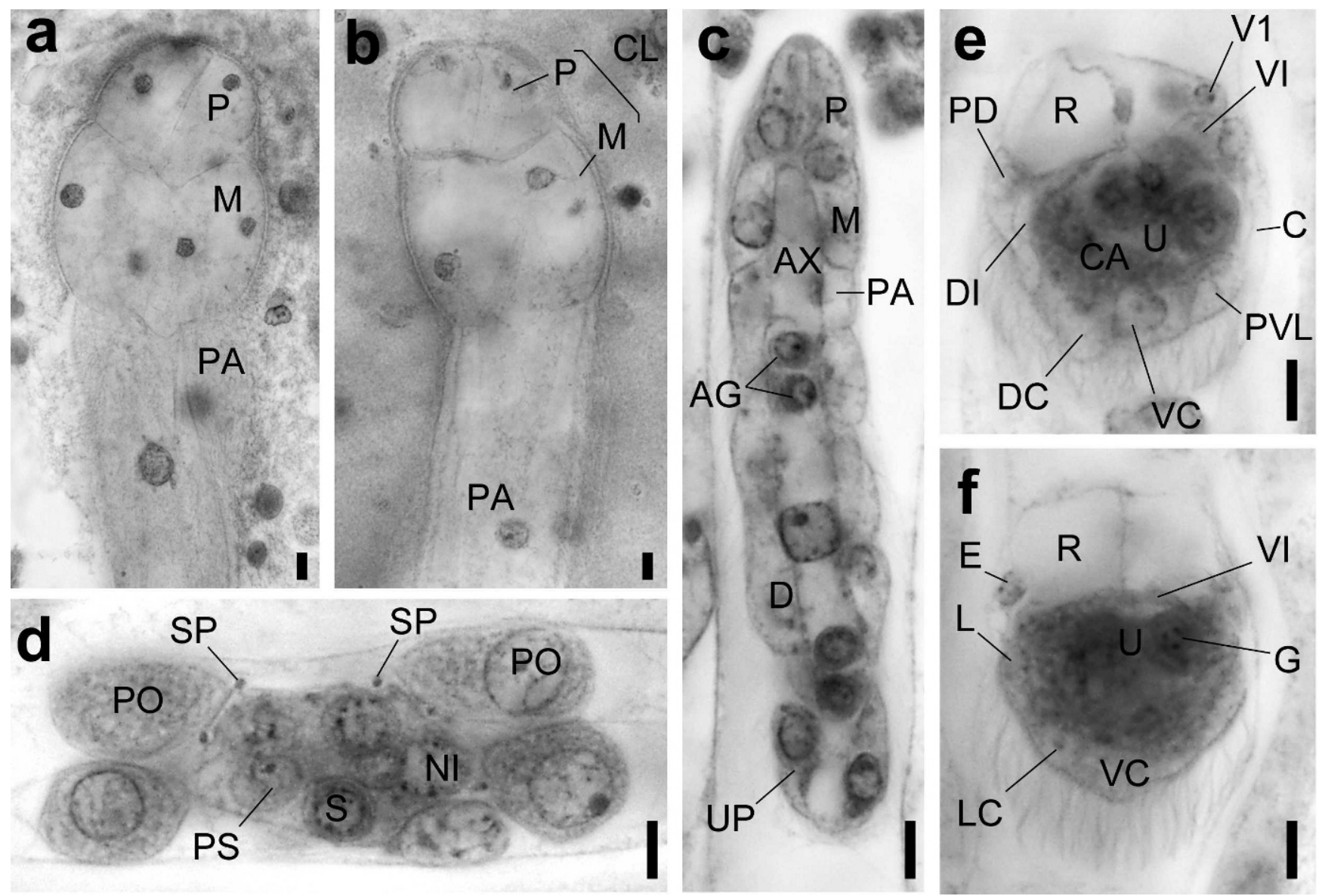

FIGURE 1. Dicyema guaycurense n. sp., photographs of specimens on slides in the syntype series (SBMNH 357585 and SBMNH 357586 ). (a) Anterior region of nematogen. (b) Anterior region of rhombogen. (c) Vermiform embryos within axial cell. (d) Infusorigen. (e, f) Infusoriform embryos within axial cell: (e) optical sagittal section; (f) optical horizontal section. Scale bars represent $5 \mu \mathrm{m}$. Abbreviations: AG, agamete; AX, axial cell; CA, capsule cell; CL, calotte; D, diapolar cell; DC, dorsal caudal cell; E, enveloping cell; L, lateral cell; LC, lateral caudal cell; M, metapolar cell; NI, nucleus of the axial cell of infusorigen; P, propolar cell; PA, parapolar cell; PD, paired dorsal cell; PO, primary oocyte; PS, primary spermatocyte; R, refringent body; S, spermatogonium; SP, sperm; U, urn cell; UP, uropolar cell; VC, ventral caudal cell; VI, ventral internal cell; V1, first ventral cell.

ventral internal cells); and internal cells without cilia (2 dorsal internal cells +2 capsule cells +4 urn cells). Each urn cell contains 1 germinal cell and 1 nucleus. All somatic nuclei appear pycnotic in mature infusoriform embryos.

\section{Taxonomic summary}

Syntypes: Allocation of type specimens on slides as follows: slides 1, 4 5, and 16 from SCM host 38 deposited in California (SBMNH 357586); slides 61-63 from SCM host 30 deposited in California (SBMNH 357585). Additional slides deposited in La Paz, Baja California Sur, México (CPMHN-UABCS 250, CPMHN-UABCS 251, CPMHN-UABCS 252).

Type host: Octopus hubbsorum Berry, 1953 (Mollusca: Cephalopoda: Octopodidae).

Symbiotype: Male (mature), 112 mm ML; SBMNH 357586.

Additional host voucher: Male (mature), $80 \mathrm{~mm}$ ML; author's collection [SCM-25].

Other hosts: None.

Type locality: México, Gulf of California, Baja California Sur, Bahia de La Paz, El Pulguero, $24^{\circ} 20^{\prime} 53.4^{\prime \prime} \mathrm{N}, 110^{\circ} 16^{\prime} 05.6^{\prime \prime} \mathrm{W}, \sim 10 \mathrm{~m}$.

Collector and date: Artesinal fisherman, 30 April 2004.

Site of infection: Anterior ends (calottes) inserted into crypts of the renal appendages within the renal sacs.

Prevalence: In 13 of 53 hosts examined (24.5\%).

Specimens deposited: Syntype slides deposited in California (SBMNH 357585, SBMNH 357586).
Etymology: The species name refers to the native people "Guaycuras" who lived in the southern region of the peninsula of Baja California, Mexico. It is expressed as a Latinized adjective in the nominative case agreeing in gender with the generic name (neuter).

\section{Remarks}

Dicyema guaycurense $\mathrm{n}$. $\mathrm{sp}$. is similar to Dicyema apollyoni, Nouvel 1947, Dicyema awajiense Furuya, 2006, Dicyema banyulensis Furuya and Hochberg, 1999, Dicyema colurum Furuya, 1999, Dicyema leiocephalum Furuya, 2006, Dicyema misakiense Nouvel and Nakao, 1938, and Dicyema shimantoense Furuya, 2008, in the number of peripheral cells, the shape of the calotte, and the anterior extent of the axial cell of the vermiform stages.

Dicyema apollyoni was described from Octopus apollyon (Berry, 1912) collected off the Marine View Rock in northern California (Nouvel, 1947) The species of the host is now known to be Octopus rubescens Berry, 1953 (F. Hochberg, unpubl. obs.). Dicyema guaycurense can be distinguished from $D$. apollyoni based on the maximum number of infusorigens (4 vs. 2 ) and the number of urn-cell nuclei of infusoriform embryos (1 vs. 2) (Nouvel, 1947; Furuya, Hochberg et al., 2004).

Dicyema banyulensis was described from Octopus salutii Verany, 1839 collected off the French coast in the western Mediterranean (Furuya and Hochberg, 1999). Dicyema guaycurense is easily distinguishable from $D$. banyulensis in the number of urn-cell nuclei of infusoriform embryos (1 vs. 2 ) and in not having swollen parapolar cells in the vermiform stages. 

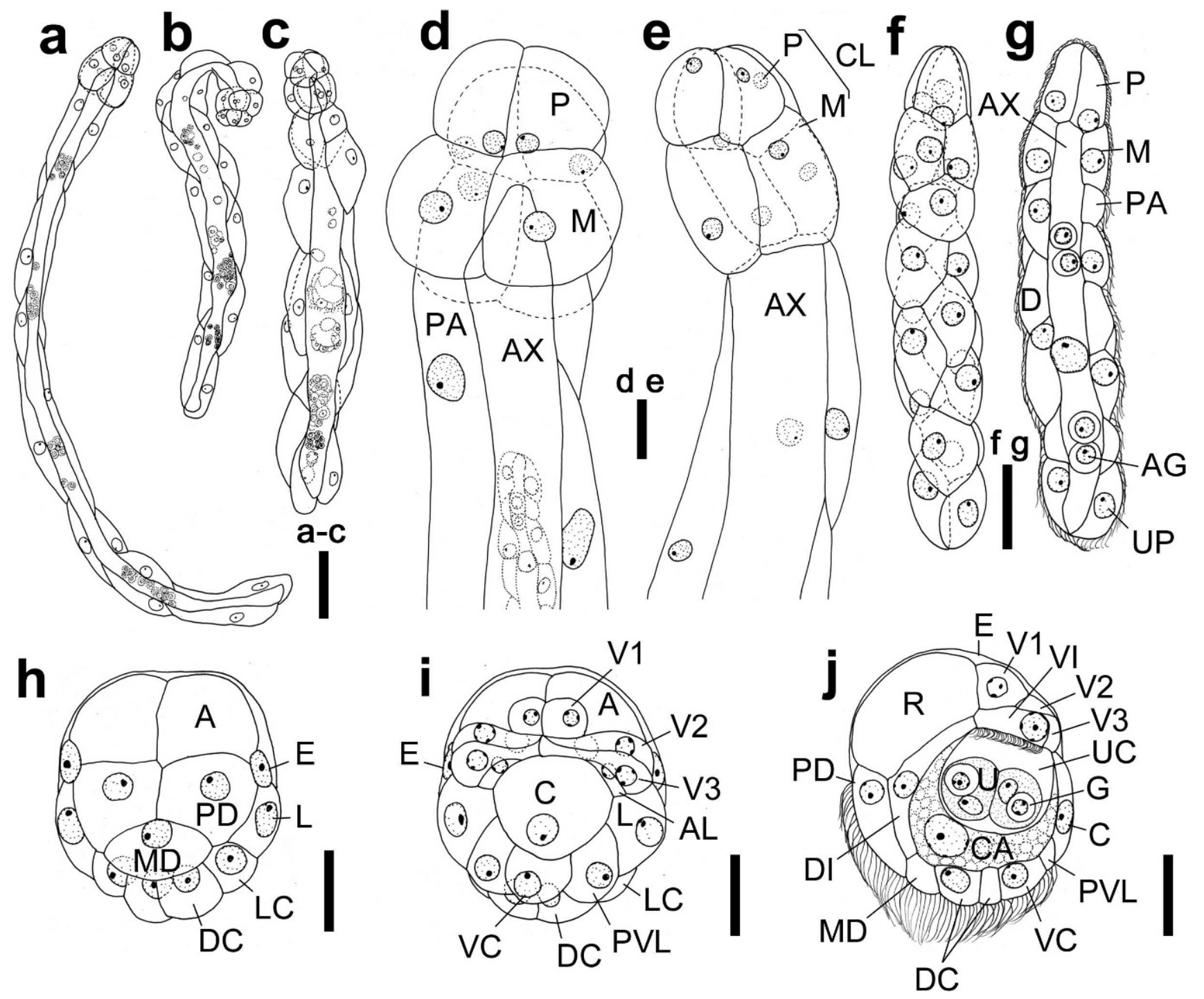

Figure 2. Dicyema guaycurense n. sp., drawn from specimens on slides in the syntype series (SBMNH 357585 and SBMNH 357586). (a-c) Vermiform stages, entire: (a) nematogen, (b, c) rhombogen. (d) Anterior region of nematogen. (e) Anterior region of rhombogen. (f, g) Vermiform embryos within the axial cell: (f) cilia omitted, (g) optical section. (h-j) Infusoriform embryos (immature): (h) dorsal view (cilia omitted), (i) ventral view (cilia omitted), (j) sagittal section. Scale bars represent $5 \mu \mathrm{m}$ in (a-c) and $10 \mu \mathrm{m}$ in (d-j). Abbreviations: A, apical cell; AG, agamete; AL, anterior lateral cell; AX, axial cell; C, couvercle cell; CA, capsule cell; CL, calotte; D, diapolar cell; DC, dorsal caudal cell; DI, dorsal internal cell; E, enveloping cell; G, germinal cell; L, lateral cell; LC, lateral caudal cell; M, metapolar cell; MD, median dorsal cell; P, propolar cell; PA, parapolar cell; PD, paired dorsal cell; PVL, posteroventral lateral cell; R, refringent body; U, urn cell; UC, urn cavity; UP, uropolar cell; V, vermiform embryo; VC, ventral caudal cell; VI, ventral internal cell; V1, first ventral cell; V2, second ventral cell; V3, third ventral cell.

Dicyema colurum and D. awaiiense were described from Amphioctopus fangsiao (d'Orbigny, 1840) collected off Japan (Furuya, 1999, 2006a). Dicyema guaycurense differs from $D$. colurum in the maximum number of agametes at eclosion of vermiform embryos (4 vs. 2) and the number of urn-cell nuclei of infusoriform embryos (1 vs. 2) (Furuya, 1999). Dicyema guaycurense can be distinguished from $D$. awajiense based on the maximum number of agametes at eclosion of vermiform embryos (4 vs. 1) and the number of cells in the infusoriform embryos (39 vs. 37) (Furuya, 2006a).

Dicyema misakisense was described from Octopus vulgaris Lamarck, 1798 collected in Japanese waters (Nouvel and Nakao, 1938). Dicyema guaycurense is distinguishable from $D$. misakisense in the maximum number of agametes at eclosion of vermiform embryos (4 vs. 2 ) and the number of cells in the infusoriform embryos (39 vs. 37) (Furuya et al., 1992b).

Dicyema leiocephalum was described from Amphioctopus areolatus (de Haan, 1840) found off Japan (Furuya, 2006b). In cellular composition of the infusoriform embryos, $D$. leiocephalum is of a particular type that possesses anterior internal cells and lacks dorsal internal cells (Furuya et al., 1997; Furuya, Hochberg et al., 2004; Furuya, 2006b). In this respect, D. guaycurense can be separated from D. leiocephalum.

Dicyema shimantoense was described from Octopus sasakii Taki, 1942 in Japanese waters (Furuya, 2008). Dicyema guaycurense is easily distinguishable from $D$. shimantoense in the maximum number of infusorigens ( 4 vs. 1) and the number of cells in the infusoriform embryos ( 39 vs. 37 ) (Furuya, 2008).

Infusorigen size and number are diagnostic characters of dicyemid species (Furuya et al., 1993). There is a negative curvilinear relationship between the number of infusorigens per rhombogen and the number of gametes (egg-line and sperm-line cells) per infusorigen (Furuya et al., 2003; Furuya, 2005, 2006a, 2006b, 2006c). Irrespective of genera, 4 distinct groups of reproductive strategies are classified within the dicyemid species: (1) rhombogens form a relatively small number of medium- to large-sized infusorigens (less than 5) and produce a relatively large number of gametes 
TABLE I. Number of peripheral cells in new species of dicyemid.

\begin{tabular}{cccc}
\hline & \multicolumn{3}{c}{ Number of individuals } \\
\cline { 2 - 4 } Cell number & $\begin{array}{c}\text { Vermiform } \\
\text { embryos }\end{array}$ & Nematogens & Rhombogens \\
\hline 20 & 0 & 0 & 1 \\
21 & 0 & 1 & 1 \\
22 & 30 & 16 & 10 \\
\hline
\end{tabular}

(more than 20) per infusorigen; (2) rhombogens produce a large number of infusorigens (more than 5), each of which has at most 20 gametes; (3) rhombogens produce large numbers of large-sized infusorigens with a large number of gametes; and (4) rhombogens form a relatively small number of small-sized infusorigens with a few gametes (at most 10) (Furuya et al., 2003; Furuya, 2005, 2006a, 2006b, 2006c). Rhombogens of $D$. guaycurense have a small number of medium-sized infusorigens, and thus this species belongs to the first type. In this respect, $D$. guaycurense differs from $D$. apollyoni (the third type), $D$. awajiense, and $D$. leiocephalum (the fourth type).

\section{DISCUSSION}

Octopus hubbsorum is a species with a robust, moderate-size body. It is commonly found in rocky areas from the intertidal to depths of $30 \mathrm{~m}$ in the shallow subtidal zone (Hochberg, 1980; Roper et al., 1995). The species ranges from Bahia de Los Angeles in the Gulf of California to Salina Cruz, Oaxaca in México. In the Mexican Pacific, O. hubbsorum is the main species that sustains the fishery (López-Uriarte et al., 2005; Alejo-Plata, 2009).

Four species of Dicyema have been reported in the region where the Baja Peninsula meets the coast of southern California, namely, Dicyema acciaccatum McConnaughey, 1949, Dicyema acheroni McConnaughey, 1949, Dicyema sullivani McConnaughey, 1941, and Dicyema apollyoni Nouvel, 1947 (McConnaughey, 1941, 1949a, 1949b). Dicyema sullivani was described in O. bimaculatus Verrill, 1883, and D. acciaccatum and D. acheroni were reported in $O$. bimaculoides Pickford and McConnaughey, 1949. The latter parasite occurs sympatrically along its range with $O$. bimaculatus, and the 2 sister species most likely occupy similar niches (Pickford and McConnaughey, 1949). Octopus bimaculatus mixes with populations of $O$. hubbsorum in the Gulf of California (Hochberg, 1980) and probably O. hubbsorum has also similar niches to these 2 species. Nevertheless, O. hubbsorum harbors only $D$. guaycurense, which has never been found in the other host octopuses. This indicates a host specificity, as Furuya (1999, 2006a) reported in the Japanese dicyemid species.

Species in Dicyema sp. commonly are found in small- to medium-sized, shallow water cephalopods (Furuya, 1999). In the present study, the prevalence of dicyemids was $24.5 \%(13 / 53)$, which is relatively low. The host octopus in which dicyemids were not found had a mantle length that measured less than $11 \mathrm{~mm}$. Furuya et al. (1992b) reported a direct relationship between host size and dicyemid occurrences, i.e., smaller or younger cephalopods of a host species generally do not harbor dicyemids. However, there are several exceptions, namely Amphioctopus fangsiao (d'Orbigny, 1840), Amphioctopus kagoshimensis (Ortmann, 1888), A. areolatus, Enteroctopus dofleini (Wülker, 1910), Octopus sasakii Taki, 1942, Sepiella japonica Sasaki, 1929, and Sepioteuthis lessoniana Lesson, 1830 (Furuya, 2005, 2006a, 2006b, 2007, 2008a, 2008b, 2008c; Furuya and Tsuneki, 2005). The absence of dicyemids in them cannot be attributed to host size, but probably to geographical location. In O. hubbsorum, the absence of dicyemids may be attributed to host size, because the specimens were sampled in a narrow area. Consequently there is probably a specific size at which the species is infected with dicyemids.

Dicyemids are known to be present in several other species of octopuses in the Gulf of California (F. Hochberg, unpubl. obs.). In addition, several potential cephalopod hosts still remain to be examined in the Gulf. Thus, a number of undescribed species of dicyemids are expected to occur in this region.

\section{ACKNOWLEDGMENTS}

We express our thanks to the fishermen from Bahía de La Paz, Baja California Sur, Mexico, Andrés González-Peralta and Hugo Ruíz, for providing samples. Thanks are also extended to the National Council of Science and Technology (CONACyT) for scholarship support. H. Furuya was supported in part by a grant from the Japan Society for the Promotion of Science (research grant 18570087).

\section{LITERATURE CITED}

Alejo-Plata, M. D. C. 2009. Reproduction, diet and fishery of Octopus (Octopus) hubbsorum (Mollusca: Cephalopoda) in the coast of Oaxaca, Mexico. Revista de Biologia Tropical 57: 63-78.

FuruYa, H. 1999. Fourteen new species of dicyemid mesozoans from six Japanese cephalopods, with comments on host specificity. Species Diversity 4: $257-319$.

. 2005. Three new species of Dicyema (Phylum Dicyemida) from Amphioctopus kagoshimensis (Mollusca: Cephalopoda: Octopodidae). Species Diversity 10: 231-247.

. 2006a. Three new species of dicyemid mesozoans (Phylum Dicyemida) from Amphioctopus fangsiao (Mollusca: Cephalopoda), with comments on the occurrence patterns of dicyemids. Zoological Science 23: 105-119.

. 2006b. Two new species of Dicyema (Dicyemida: Dicyemidae) from Amphioctopus areolatus (Mollusca: Cephalopoda: Octopodidae). Species Diversity 11: 257-269.

. 2006c. A new species of Dicyemennea Whitman, 1883 (Phylum Dicyemida) from Sepia latimanus (Mollusca: Cephalopoda: Decapodidae) off Okinawa, Japan. Systematic Parasitology 65: 205-213.

- 2007. Redescription of two Dicyemennea (Phylum: Dicyemida) from Rossia pacifica (Mollusca: Cephalopoda: Decapoda). Journal of Parasitology 93: 841-849.

. 2008a. A new dicyemid from Sepiella japonica (Mollusca: Cephalopoda: Decapoda). Journal of Parasitology 94: 223-229. - 2008b. Three new dicyemids from Octopus sasakii (Mollusca: Cephalopoda: Octopoda). Journal of Parasitology 94: 1064-1070. - 2008c. Redescription of Dicyemennea nouveli (Phylum: Dicyemida) from Enteroctopus dofleini (Mollusca: Cephalopoda: Octopoda). Journal of Parasitology 94: 1071-1081.

- R. T. Damian, and F. G. Hochberg. 2002. A new species of Dicyema (Phylum Dicyemida) from Octopus burryi (Mollusca: Cephalopoda) in the Gulf of Mexico. Journal of Parasitology 88: 325-329.

- and F. G. Hochberg. 1999. Three new species of Dicyema (Phylum Dicyemida) from cephalopods in the western Mediterranean. Vie et Milieu 49: 117-128.

, AND K. TsuneKI. 2003. Reproductive traits of dicyemids. Marine Biology 142: 693-706.

- AND _ 2004. Cell number and cellular composition in infusoriform larvae of dicyemid mesozoans (Phylum Dicyemida). Zoological Science 21: 877-889.

, AND K. TsuneKi. 2005. A new species of dicyemid mesozoan (Dicyemida: Dicyemidae) from Sepioteuthis lessoniana (Mollusca: Cephalopoda), with notes on Dicyema orientale. Species Diversity 10: $45-62$.

, - AND Y. Koshida. 1992a. Development of the infusoriform embryo of Dicyema japonicum (Mesozoa: Dicyemidae). Biological Bulletin 183: 248-257. 

Dicyema (Mesozoa) from octopuses of Japan with notes on $D$. misakiense and D. acuticephalum. Zoological Science 9: 423-437.

- $\longrightarrow$ AND 1 1993. The development of the hermaphroditic gonad in four species of dicyemid mesozoans. Zoological Science 10: $455-466$.

- - AND $\longrightarrow$ 1997. Fine structure of a dicyemid mesozoan, Dicyema acuticephalum, with special reference to cell junctions. Journal of Morphology 231: 297-305.

HochberG, F. G. 1980. Class Cephalopoda. In Common intertidal invertebrates of the Gulf of California, R. C. Brusca (ed.). University of Arizona Press, Tucson, Arizona, p. 201-204.

López-Uriarte, E., E. Ríos-Jara, and M. Pérez-Peña. 2005. Range extension for Octopus hubbsorum Berry, 1953 (Mollusca: Octopodidae) in the Mexican Pacific. Bulletin of Marine Science 7: 171-176.

McConnaughey. B. H. 1941. Two new Mesozoa from California, Dicyemennea californica and Dicyemennea brevicephala (Dicyemidae). Journal of Parasitology 27: 63-69.

. 1949a. Mesozoa of the Family Dicyemidae from California. University of California Publications in Zoology 55: 1-34. 1949b. Dicyema sullivani, a new mesozoan from lower California. Journal of Parasitology 35: 122-124.

Nouvel, H. 1947. Les Dicyémides. 1re partie: Systématique, générations, vermiformes, infusorigène et sexualité. Archives de Biologie 58: 59 220.

1948. Les Dicyémids. 2é partie: Infusoriforme, tératologie, spécificité, du parasitisme, affinités. Archives de Biologie 59: 147-223. , AND Y. NAKaO. 1938. Dicyémides du Japon. Bulletin de la Société Zoologique de France 63: 72-80.

Pickford, G. E., and B. H. McConnaughey. 1949. The Octopus bimaculatus problem: A study in sibling species. Bulletin of the Bingham Oceanographic Collection 12: 1-66.

Roper, C. F. E., M. J. Sweeney, and F. G. Hochberg. 1995. Cefalópodos. In Guía Fao para la Identificación para los Fines de la Pesca. Pacifico Centro-Oriental, Vol. I., W. Fischer, F. Krupp, W. Schneider, C. Sommer, K. E. Carpenter, and V. H. Niem (eds.). Plantas e Invertebrados, Roma, Italia, p. 306-353.

Short, R. B., and R. T. Damian. 1966. Morphology of the infusoriform larva of Dicyema aegira (Mesozoa: Dicyemidae). Journal of Parasitology 52: 746-751. 